\title{
EFFECTS OF PROTEINASE INHIBITORS FROM MOMORDICA COCHINCHINENSIS ON SEVERAL MEAT-SPOILAGE BACTERIA
}

\author{
Tran Thi Loan, Pham Thi Tran Chau* \\ Institute of Microbiology and Biotechnology (IMBT), *chauptt@vnu.edu.vn
}

\begin{abstract}
This study aims at primarily investigating the effects of Momordica cochinchinensis proteinase inhibitors (MCoPIs) on several common meat-spoilage bacteria. The obtained results showed that the MCoPIs solution inhibited the growth of 4 studied bacteria: Bacillus cereus, Bacillus cereus 3, Bacillus cereus 81 and Escherichia coli. The proteinase activity (PA) of the bacterial broths supernatants reached the highest level after culturing $48-60 \mathrm{hrs}$, at $200 \mathrm{rpm}$ and $37^{\circ} \mathrm{C}$. The best PA of the studied bacteria was around $\mathrm{pH}=7.6$. Using PAG containing casein electrophoresis method, several clarified PA bands on dark blue ground were detected from broths supernatants of these bacteria. However, after treatment with MCoPIs solution most of these PA bands were less or disappeared. Treatment of meat with MCoPIs solution showed a positive effect on the freshness of meat. After 16hrs, only the meat samples treated with MCoPIs were remained fresh, while the control samples became rancid. Moreover, the soluble proteins as well as hydrolytic products from samples treated with MCoPIs solution were about 1,5-2 times lower than those of the corresponding control samples. The results indicated an applicable potentiality of MCoPIs solution for protection of meat from bacterial infection and prolonging meat freshness.
\end{abstract}

Keywords: B. cecreus, E. coli, Momordica cochinchinensis, anti-bacterial activity, proteinase inhibitors.

\section{INTRODUCTION}

Bacterial infection is the most common agent for food poisoning and its main target is raw meat. The Vietnamese Ministry of Health has restricted certain bacteria in meat e.g. Escherichia coli, Bacillus cereus etc. [2]. These bacteria strongly grow on the surface of raw meat and have high proteolytic activity (PA) hydrolyzing meat-protein into polypeptides and other products with rancid smelling (e.g: NH3, indole, scatol, mercaptans, etc.) or toxins (putrescine, cadaverinem...). There are different methods restricting the bacterial infection such as chemicals, irradiation, frozen... but these factors may cause unpleasant odor, unusual color of meat and other disadvantages [6, 4]. Our previous studies showed that PPIs isolated from Momordica cochinchinensis seeds (named MCoPIs) can strongly inhibit the growth of bacteria $[5,6]$. However, there has not yet been found any publication using these PPIs to prevent bacterial infection of meat. This study aims at primarily investigating the effects of MCoPIs on several common meat-spoilage bacteria.

\section{MATERIALS AND METHODS}

\section{Materials}

Studied bacteria: 11 strains isolated from meat, supplied by the National Institute of Nutrition (NIN): E. coli UN, Staphylococcus aureus, Salmonella 3, B. cereus 81, S. aureus $21, S$. aureus $\mathrm{CN}$, B. cereus 3, B. cereus $\mathrm{BC}$, S. aureus CQ, Salmonella LH, B. cereus $114, E$. coli 1; 5 wild type samples supplied by The Institute of Microbiology and Biotechnology (IMBT, Vietnam National University at Hanoi): Salmonella sp., E. coli, B. cereus, S. aureus, Vibrio parahaemolyticus.

MCoPIs (41.1 mIU/ml, $1.1 \mathrm{mg}$ protein $/ \mathrm{ml})$ were partially purified by Sephadex G-75 column chromatography.

\section{Methods}

Antibacterial activity assay by diffusion method: The bacterial broth was mixed with a culture medium containing agar, poured on the plate, then MCoPIs solution was added to the wells had been made on the agar plate. The activity was determined by measuring the diameter $(\mathrm{D}, \mathrm{cm})$ of clarified zone.

Proteolytic activity (PA) assay: by diffusion method. The medium contained $0.1 \%$ casein. 
The PA was determined basing on measuring the clarified zone diameter $(\mathrm{D}, \mathrm{cm})$ on the dark blue ground.

Proteinase inhibitory activity (PIA) assay: by diffusion method. PA of bacteria was treated with MCoPIs for 10 minutes before added to the wells. The control sample was PA of bacteria plus water in the same volume of MCoPIs solution. All plates were incubated at $37^{\circ} \mathrm{C}$ for $8 \mathrm{hrs}$.

Evaluate freshness of sliced meat samples by Ebe method Observation of white smoke $\left(\mathrm{NH}_{4} \mathrm{Cl}\right)$ appearing around meat samples. The smoke was appeared when meat became rancid.

Determine hydrolytic products: by the color reaction with Folin-Ciocalteu reagent. Meat sample extract or meat fluid was centrifuged, supernatants were subjected to analyse with Folin-Ciocalteu reagent then measured the absorbance at $750 \mathrm{~nm}$ wave length.

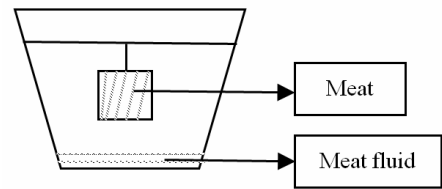

Protein content was determined by using Lowry method

Using PAGE to detect PA and PIA: 2 pieces of PAG coo-polymerized with casein were carried out electrophoresis in parallel. One of them was soaked in Sorensen buffer $(\mathrm{Ph}=7.6)$ for detection of PA and another one was soaked in MCoPIs solution to detect PIA. The PA was appeared as a clarified band on the dark blue background, in the presence of PA inhibitor the PA band(s) were less clear or disappeared.

\section{RESULTS AND DICUSSION}

\section{Antibacterial activity of MCoPIs solution}

Table 1. Antibacterial activity of MCoPIs solution

\begin{tabular}{|c|l|c|}
\hline Number & Strain & $\begin{array}{c}\text { Diameter of } \\
\text { antibacterial zone } \\
(\mathrm{D}, \mathrm{cm})\end{array}$ \\
\hline 1 & B. cereus & 1.8 \\
\hline 2 & E. coli & 1.6 \\
\hline 3 & B. cereus 81 & 1.7 \\
\hline 4 & B. cereus 3 & 1.8 \\
\hline
\end{tabular}

The results showed that among 16 studied bacteria, only four bacteria were inhibited by MCoPIs. They were: $B$. cereus, B. cereus $3, B$. cereus $81, E$. coli with antibacterial zone diameters of 16-18 $\mathrm{mm}$ (fig. 1 and table 1).

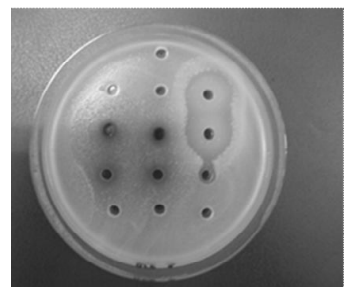

a. B. cereus 3

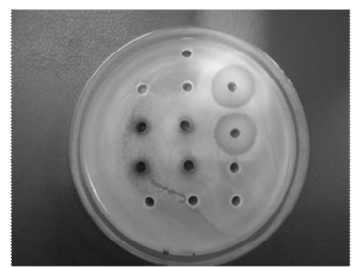

c. B. cereus

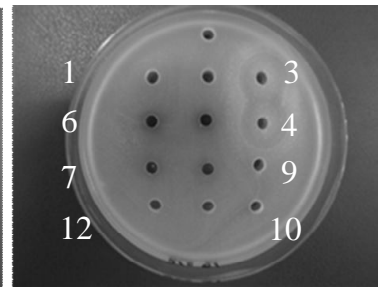

b. B. cereus 81

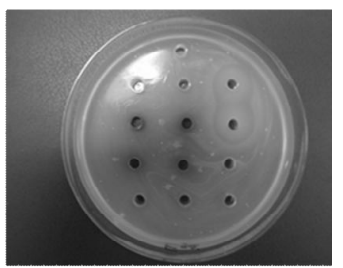

d. E. coli
Fig.1. Antibacterial activity of extracts from several plant samples

1. Water; 2. Acetic acid $0.02 \mathrm{M}$; 3-4. MCoPIs solution; 5-6. Zanthoxylum avicennae extract by water; 7-8. Zanthoxylum avicennae extract by acetic acid 0.02 M; 9-10. Mormodica cochinchinesis extract by water; 11-12. Mormodica cochinchinesis extract by acetic acid $0.02 \mathrm{M}$.

\section{Effect of culture times on PA of bacteria}

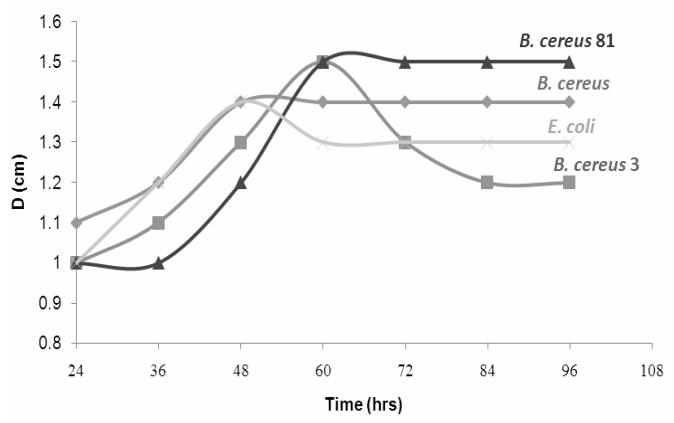

Fig. 2. Effect of culture time on the PA of bacteria

Fig. 2 showed that PA of these four bacteria reached highest level after culturing 48-60hrs. After $60 \mathrm{hrs}$, the PA of B. cereus, B. cereus 81 and $E$. coli was almost not changed and the PA of $B$. cereus 3 decreased strongly; PA of these bacteria at the chosen time was presented on fig.3. 


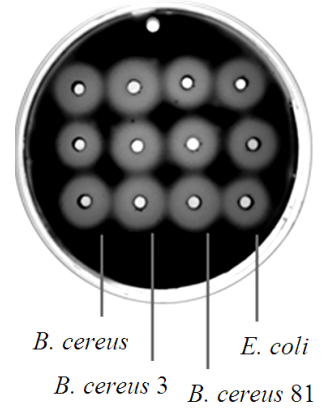

Fig. 3. PA of bacteria at the chosen time

\section{Effect of pH on PA from studied bacteria}

After choosing the culture time, the PA of these bacteria was determined at 4 different $\mathrm{pH}$ values (6, 7, 7.6 and 9). The results showed that the highest PA of these studied bacteria was around $\mathrm{pH}=7.6$ (fig.4).

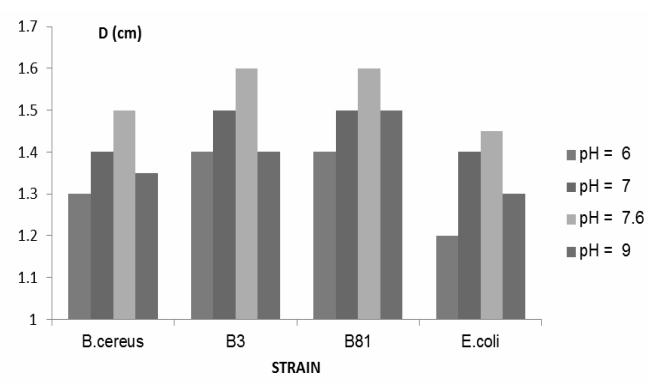

Fig. 4. Effect of $\mathrm{pH}$ on PA of bacteria

\section{Effect of MCoPIs on PA of bacteria (or PIA of MCoPIs)}

The experiment was carried out at $\mathrm{pH}=7.6$. Fig. $5 \& 6$ and Table 2 indicated that PA of all bacteria was strongly inhibited by MCoPIs. Moreover, PA of B. cereus 3 and B. cereus 81 was inhibited stronger than that of the others.

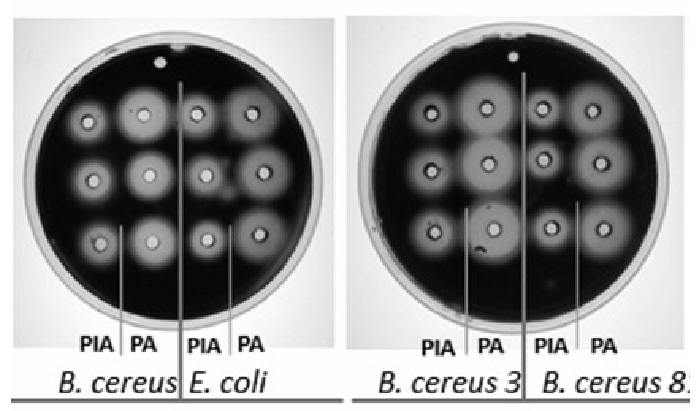

Fig. 5. Effect of MCoPIs on PA of bacteria
Table 2. The PIA of MCoPIs to the studied bacteria

\begin{tabular}{|l|c|c|c|}
\hline \multicolumn{1}{|c|}{ Strain } & $\begin{array}{c}\text { PA } \\
(\mathrm{D} 1, \mathrm{~cm})\end{array}$ & $\begin{array}{c}\text { PIA } \\
(\mathrm{D} 2, \mathrm{~cm})\end{array}$ & $\begin{array}{c}\mathrm{D} 1-\mathrm{D} 2 \\
(\mathrm{~cm})\end{array}$ \\
\hline B. cereus & 1.5 & 1.2 & 0.3 \\
\hline B. cereus 3 & 1.6 & 1.0 & 0.6 \\
\hline B. cereus 81 & 1.6 & 1.0 & 0.6 \\
\hline E. coli & 1.45 & 1.2 & 0.25 \\
\hline
\end{tabular}

Note: In the presence of inhibitors, diameter of clarified PA zone $\left(D_{1}\right)$ was reduced $\left(D_{2}\right)$. Proteinase inhibitory activity (PIA) equal $\mathrm{D}_{1}-\mathrm{D}_{2}$.

Using PAG co-polymerized with casein (fig. 6) for detection of PA and PIA also showed that after treatment with MCoPIs solution, PA bands of $B$. cereus 3 and $B$. cereus 81 were disappeared (land $2 \& 3$ ), while PA bands of $B$. cereus still observed but the number of bands was less and not clear (land 1).

The above results indicated that MCoPIs solution can be used for protection of meat from bacterial infection.

\section{Effect of MCoPIs solution on meat freshness}

Evaluate meat freshness by using Ebe method

This experiment was carried out with a fresh meat pieces (taken from slaughter-house) with the size of $8 \times 5 \times 1.5 \mathrm{~cm}$. These samples were divided into 4 groups and treated in different ways: 1. treated with water; 2 . treated with MCoPIs solution; 3. covered by bacteria (each sample was covered by one of these bacteria); 4 . covered by bacteria, then covered by MCoPIs solution. All samples were kept at $37^{\circ} \mathrm{C}$. Observation was carried out at certain time intervals (12; 16; 20 and 28 hrs). Rancid level (or freshness level) of meat was evaluated basing on an appearance of white smoke around meat samples. After $16 \mathrm{hrs}$, the control samples were unfresh while the samples 2 and 4 were still fresh. Moreover, even after $28 \mathrm{hrs}$ the sample 2 was only less fresh, while the other samples were rancid (fig. 7).

Fresh meat was cut into pieces $(8 \times 6 \times 1.5$ $\mathrm{cm}$ ) and treated with a determined amount of MCoPIs solution, storaged at $37^{\circ} \mathrm{C}$ at interval time observed white smoke around meat samples. A control samples were made in 
parallele but MCoPIs solution was replaced by water. After $20 \mathrm{hrs}$, the samples treated with MCoPIs were remaining fresh while the other samples were less fresh. These experiment samples (treated with MCoPIs solution) were only less fresh while other samples were rancid.

From these above results, only the samples 1 and 2 after 28 hrs treatment was taken for

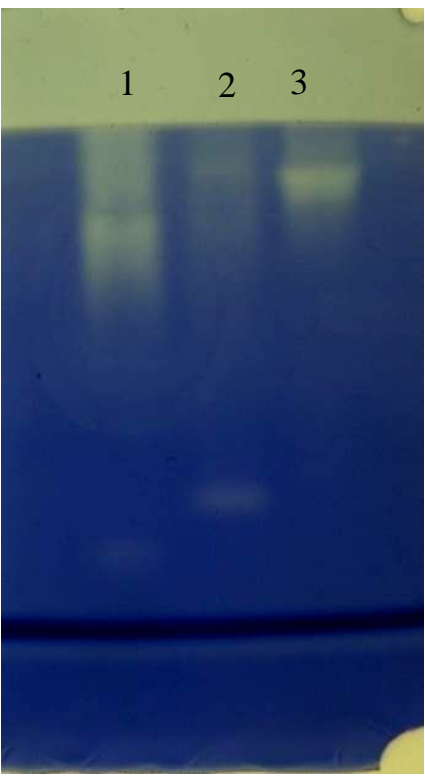

a. PA

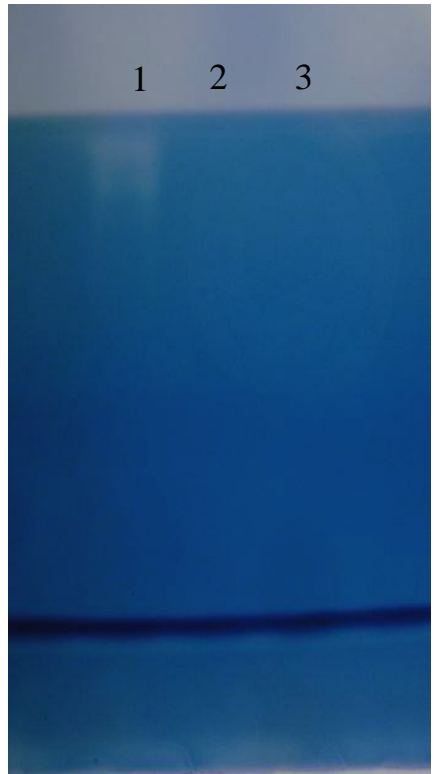

b. PIA
Fig. 6. Electrophoregram of PA (a) and PIA (b) of the studied $B$. cereus

1. B. cereus 3 ; 2. B. cereus $81 ; 3$. B. Cereus.

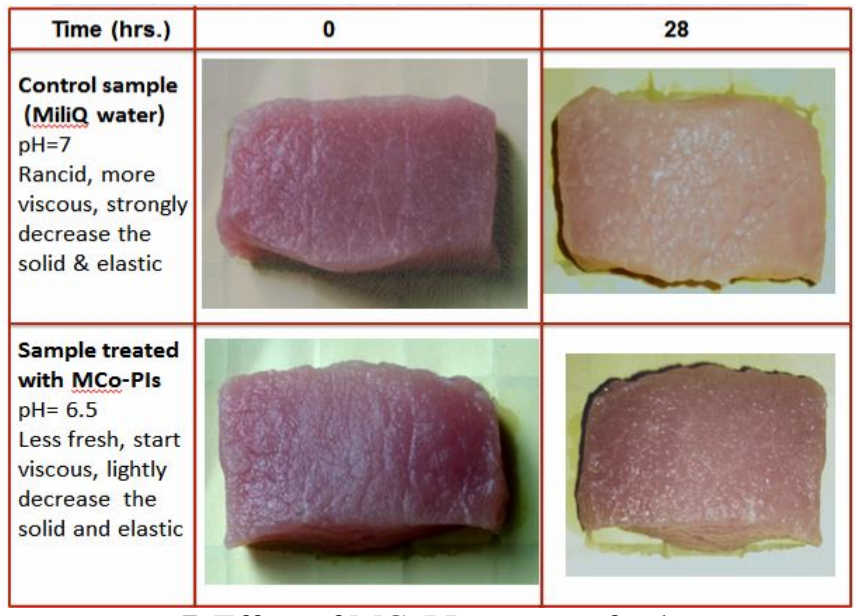

Fig. 7. Effect of MCoPIs on meat freshness futher study. The exeperiment was carried out as follows: water was added to the sample 1 and 2 with the same certain amount then voltex, the suspensions were decanted to tubes. As it showed on Fig. 8, the crumbs amount of sample 1 was much more than that of sample 2, while the weight of remainders (left meat) of sample 2 was higher than that of sample $1(89 \%$ and $71 \%$, respectively).

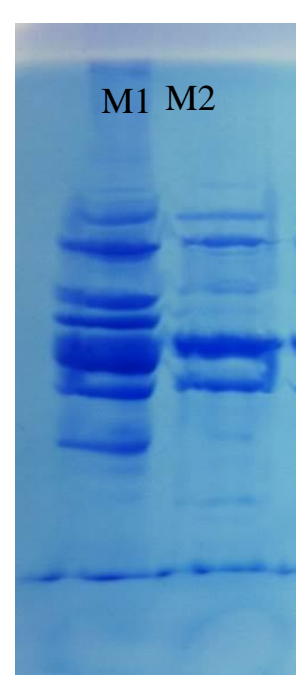

Fig. 9. Detect soluble protein bands of meat samples (from fig. 7) by SDS-PAGE

1. Meat $+\mathrm{H}_{2} \mathrm{O}$; 2. Meat + MCoPIs (extract from pumkin seeds); Each meat sample was ground, water was added in the ratio $5 \mathrm{ml} / 1 \mathrm{~g}$ of meat then shaked $200 \mathrm{rpm} / \mathrm{min}$, centrifuged at 10,000 $\mathrm{rpm} / \mathrm{min}$, soluble proteins in supernatant was analyzed by SDSPAGE.

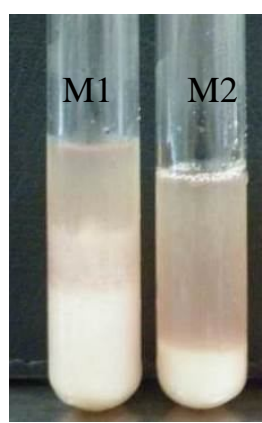

Fig. 8. The suspensions of meat samples 1 and 4 
To evaluate more details the effect of MCoPIs on meat freshness; we have carried out to determine the amount of soluble proteins and hydrolytic products of these meat samples.

The soluble proteins and the hydrolytic products of meat

Using SDS- PAGE to detect soluble protein bands of the sample 1 and 2 showed that the number of protein bands of the control sample was more than that of experimental samples, especially in the area of bands with high molecular mass (fig. 9).

The amount of hydrolytic products from all samples treated with MCoPIs was lower from 1.5 to over 2 times than that of the corresponding control samples (Fig.10B \& 10D). It means that the samples treated with MCoPIs were less spoilage than the others. The amount of total soluble proteins determined by

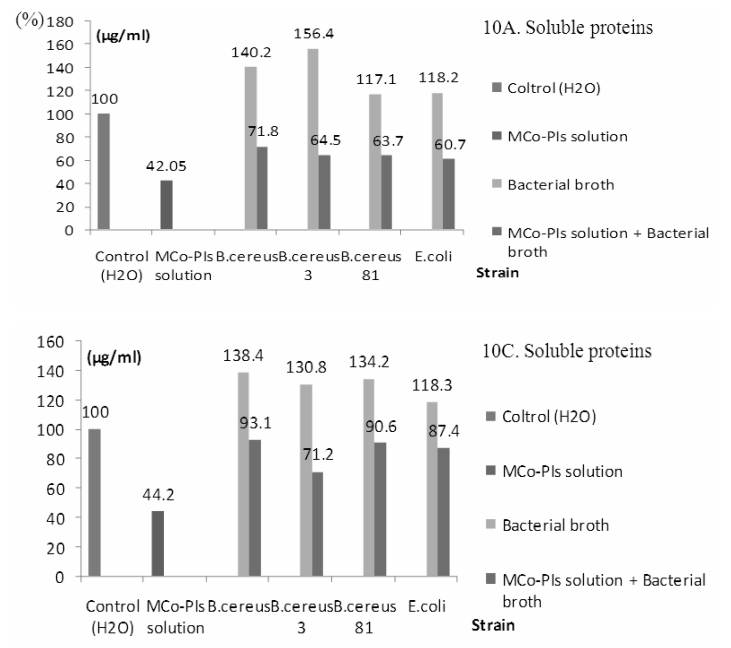

Lowry method was given a similar result (fig. $10 \mathrm{~A} \& 10 \mathrm{C})$. These results also indicated that the MCoPIs having clearly positive effect on preventing meat from bacterial infection and delaying the meat spoilage process.

Soluble protein analysis: extract from meat samples was prepared as follows: each meat sample was ground, water was added in the ratio $5 \mathrm{ml} / 1 \mathrm{~g}$ of meat then shaked $200 \mathrm{rpm} / \mathrm{min}$, centrifuged at $10000 \mathrm{rpm} / \mathrm{min}$, soluble proteins in supernatant was analyzed by Lowry method. In case of meat fluid (collected from the bottom of experiment box), it was centrifuged and the supernatant was analyzed.

Hydrolytic products: the supernatant of meat extract or meat fluid was precipated with TCA, final concentration of TCA in the mixture reached $5 \%$, and then the filtrate was subjected for analysis of hydrolytic products with the Folin - ciocalteu reagent.
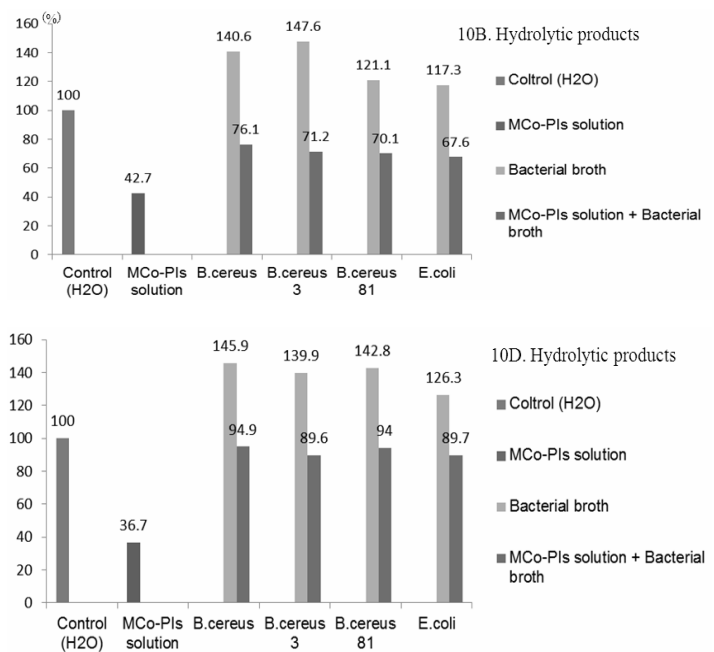

Fig. 10. The soluble proteins and hydrolytic products of sliced meat A and B: extract from meat; C and D: meat fluid; A and C: soluble proteins; B and D: hydrolytic products.
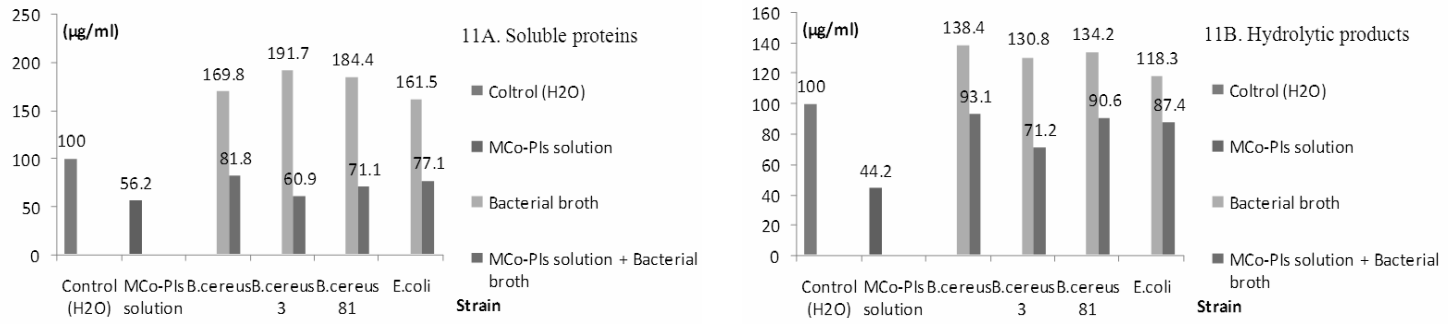

Fig. 11. The soluble proteins and hydrolytic products of ground meat 
Meat samples were prepared for analyzing soluble proteins and hydrolytic products as description in fig. 10.

In case of ground meat, the differences between the control and experiment samples were most obvious (Fig 11): the amount of hydrolytic products of the sample soaked with broth of $B$. cereus 3 before treated with MCoPIs was 3.14 times higher than that of the corresponding control samples (fig. 11A).

\section{CONCLUSION}

Among 16 tested bacteria, the growth of 04 bacteria $B$. cereus, B. cereus $3, B$. cereus 81 and $E$. coli. were strongly inhibited by MCoPIs solution.

The proteolytic activity (PA) of these bacteria reached highest level after culturing 48$60 \mathrm{hrs}$ at $200 \mathrm{rpm}$ and $37^{\circ} \mathrm{C}$. PA of these bacteria rather high at reaction $\mathrm{pH}$ around 7.6.

Using electrophoresis method on PAG containing casein, several clarified PA bands on dark blue ground were detected from broth supernatants of these bacteria. However, after treatment with MCoPIs solution, most of these PA bands were less or disappeared.

A trial using MCoPIs solution for protection of meat was done. After $16 \mathrm{hrs}$, the control samples were unfresh while the samples treated with MCoPIs were still fresh. The amount of soluble proteins and hydrolytic products from the experiment samples was lower from 1.5 to over 2 times than that of without treated with
MCoPIs corresponding samples. The analyzing results also indicated that the positive effect of MCoPIs on keeping freshness of meat and delaying meat-spoilage process dues to their inhibitory activity against PA of bacteria $(B$. cereus, B. cereus 3, B. cereus 81, E. coli) associated with meat.

\section{REFERENCES}

1. Pham Thi Tran Chau, 2007. Concise report on study of proteinase inhibitors and their utilization in practice (from 1986-July 2007), Proceeding of The 2nd International Conference on the development of Biomedical engineering in Vietnam, Hanoi, 196.

2. Pham Thi Tran Chau, Hang M. T., Hao V. T., Ha N. H., Dung N. L., 1998. Effect of Momosertatin on the growth of microorganisms, 8 th. FAOBMB Congress. Kuala Lumpur, Malaysia, Abstracts C26.

3. Davidson P. M., Sofos J. N. , Branen A. L., 2005. Antimicrobials in foods, Taylor and Francid Group.

4. John N. S., 2005. Improving the safety of fresh meat, Woodhead Publishing Limited, Cambridge England.

5. Bùi Thị Như Thuận, Nguyễn Phùng Tiến, Bùi Minh Đức, 1991. Kiểm nghiệm chất luợng và thanh tra vệ sinh an toàn thực phẩm. Nxb. Y học.

6. http://www.cdc.gov/foodsafety/cdc-andfood-safety.html 


\title{
HIỆU QUẢ CỦA CHẤT Ú̉C CHẾ PROTEINASE TÙ HẠT GẤC (MOMORDICA COCHINCHINENSIS ) ĐỐI VỚI MỘT SỐ VI KHUẦ GÂY HỎNG THỊT
}

\author{
Trần Thị Loan, Phạm Thị Trân Châu
}

Viện Vi sinh vật và Công nghệ sinh học, ĐHQG Hà Nội

\section{TÓM TÁ́T}

Mục đích chính của bài báo này nhằm bước đầu thăm dò tác dụng của các chất ức chế chiết xuất từ hạt gấc (MCoPIs) đối với một số vi khuẩn phổ biển gây hỏng thịt. Kết quả thu được cho thấy trong số 16 chủng nghiên cứu, dung dịch MCoPIs có khả năng ức chế sự sinh trưởng của 4 chủng vi khuẩn: Bacillus cereus, Bacillus cereus 3 , Bacillus cereus 81 và Escherichia coli. Các chủng vi khuẩn này có hoạt tính proteinaz (PA) cao nhất sau 48-60 giờ nuôi lắc 200 vòng/phút ở $37^{\circ} \mathrm{C}$. PA của các vi khuẩn này hoạt động tốt nhất ở khoảng $\mathrm{pH}=7,6$. Dùng phuơng pháp điện di trên gel polyacrylamide có chứa casein đã phát hiện được các băng PA của 4 chủng nghiên cứu. Tuy nhiên, sau khi xử lý với dung dịch MCoPIs thì số lượng các băng PA đã bị giảm đi hoặc mất hoàn toàn. Thịt được xử lý với dung dịch MCoPIs vẫn còn tươi trong vòng 16 giờ trong khi các mẫu thịt đối chứng đã bị ôi. Thêm vào đó, lượng sản phẩm thủy phân cũng như protein tan của các mẫu thịt qua xử lý với MCoPIs thấp hơn khoảng 2 lần so với các mẫu đối chứng tương ứng. Các kết quả trên cho thấy tiềm năng ứng dụng MCoPIs để bảo quản thịt.

Từ khóa: Bacillus cereus, E. coli, Momordica cochinchinensis, hoạt tính kháng khuẩn, ức chế proteinase.

Ngày nhận bài: 4-3-2013 